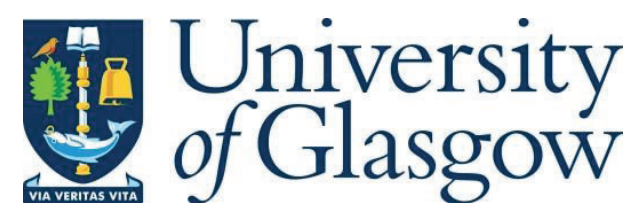

McPherson, R. (2021) Diminished responsibility post codification: lost opportunities, tensions and gendered applications. Edinburgh Law Review, 25(2), pp. 173-191.

(doi: 10.3366/elr.2021.0693).

There may be differences between this version and the published version. You are advised to consult the publisher's version if you wish to cite from it.

$\underline{\text { http://eprints.gla.ac.uk/232683/ }}$

Deposited on: 26 January 2021

Enlighten - Research publications by members of the University of Glasgow http://eprints.gla.ac.uk 


\title{
Diminished responsibility post codification: lost opportunities, tensions and gendered applications
}

\author{
Dr Rachel McPherson*
}
A. INTRODUCTION
B. THE DEVELOPMENT OF A STATUTORY PLEA

(1) Common law development

(2) Reviews of the law in this area

(3) The introduction of a statutory definition

C. POST CODIFICATION CASES

D. BURDEN AND STANDARD OF PROOF

(1) Discharging the reverse burden

(2) Defining the standard of proof

E. WHERE MENTAL ABNORMALITY COEXISTS WITH VOLUTARY INTOXICATION

(1) Clarifying the rule

(2) A narrow approach post codification

(3) Tensions and contradictions

F. DEPENDENCY

(1) Potentially relevant Scottish cases

(2) The Court of Appeal in England and Wales

(3) Medico-legal analysis

G. CONCLUSION

* Lecturer in Criminal Law, University of Glasgow. With thanks to Professor James Chalmers (University of Glasgow) and Elaine Ferguson (Risk Management Authority) for their comments on earlier drafts of this paper. 


\begin{abstract}
Following from the Scottish Law Commission's Report on Insanity and Diminished Responsibility, the Criminal Justice and Licensing (Scotland) Act 2010 codified the plea of diminished responsibility. Part of the justification for this codification arose from the need to clarify the rule in relation to drugs and alcohol. With this change there existed scope to develop the plea in a way which appreciated the complex interplay between mental conditions and intoxication- something which was absent under common law. At a time when mental health law is under review in Scotland, this article seeks to examine the landscape of diminished responsibility, asking whether $51 \mathrm{~B}$ is able to properly appreciate the realities of offending and whether it is applied to all accused fairly and consistently.
\end{abstract}

Keywords: Diminished responsibility; mental conditions; intoxication; addiction; gendered applications of the law

\title{
A. INTRODUCTION
}

This article maps the landscape of diminished responsibility in Scotland following codification of the plea. It focuses particularly on how the interaction between mental abnormality and voluntary intoxication has been understood. In addition to considering recent decisions by the Scottish appeal court, this article presents analysis from 29 unreported cases in which diminished responsibility was pled.

The examination which will follow is timely: an independent review of mental health law is currently being undertaken, questioning whether current mental health law promotes and protects human rights in Scotland. ${ }^{1}$ Concerns relating to access to diminished responsibility do not simply centre around appropriate convictions: the plea can and does act as an appropriate gateway to mental health care and treatment for those in need.

\footnotetext{
${ }^{1}$ Scottish Government, Overview of the Review of Mental Health Law in Scotland, available at https://consult.gov.scot/mental-health-law-secretariat/review-of-mental-health-law-inscotland/
} 
It will be concluded that the appeal court has adopted a narrow interpretation in relation to the interaction between mental abnormality and voluntary intoxication. This not only undermines the justifications which were made for placing diminished responsibility in statutory form, it moves the plea towards a position of being unable to appreciate the realities of mental health conditions and circumstances in which people offend. It will be shown that tensions exist between the appeal court's approach and the operation of the plea in practice, and that whilst operation in practice might offer more opportunity for access to the defence, it may also be perpetuating gender stereotypes about female offending.

\section{B. THE DEVELOPMENT OF A STATUTORY PLEA}

\section{(1) Common law development}

Described as "distinctively Scottish." ${ }^{\text {, }}$ diminished responsibility developed throughout early $20^{\text {th }}$ caselaw - even if not always referred to by the same terminology. ${ }^{3}$ This development influenced legislation in other jurisdictions- notably England and Wales where it was introduced through the Homicide Act 1957 (although as Loughnan notes, the focus of attention at that time was on capital punishment rather than diminished responsibility). ${ }^{4}$

Historically, the plea required that a mental disease or a state of mind virtually bordering on insanity be shown. ${ }^{5}$ Modern formulation arose from Galbraith $^{6}$ where it was accepted that the earlier authority of Savage ${ }^{7}$ had been misinterpreted in Connelly ${ }^{8}$ In particular, misunderstanding had arisen regarding the requirement that the accused be suffering from a 'mental disease' and was required to satisfy the four criteria set out in Savage. ${ }^{9}$ Agreeing this point on appeal, it was clarified that: there must be an abnormality of mind and that this abnormality substantially impaired the accused's ability to control their conduct; that a mental disease was not required to satisfy the plea and that the criteria in Savage did not need

\footnotetext{
${ }^{2}$ J Chalmers and F Leverick, Criminal Defences and Pleas in Bar of Trial (2006) para 11-01. ${ }^{3}$ Ibid

${ }^{4}$ A Loughnan, Manifest Madness (2012) 233.

${ }^{5}$ HM Advocate v Savage 1923 JC 49.

${ }^{6}$ Galbraith v HM Advocate (No 2) 2002 JC 1.

${ }^{7}$ HM Advocate v Savage 1923 JC49.

${ }^{8}$ Connelly v HM Advocate 1990 JC 349.

${ }^{9}$ An aberration or weakness if mind; a state of mind bordering on but not amounting to insanity; mental unsoundness; and a mind so affected that criminal responsibility can only be partial.
} 
to be adhered to absolutely- instead only being an indication of what an accused would need to prove.

\section{(1) Reviews of the law in this area}

Shortly before the decision in Galbraith, the Millan Committee published their Review of the Mental Health (Scotland) Act 1984, recommending amongst other things that the Scottish Law Commission be invited to review the defence of diminished responsibility. ${ }^{10}$ They noted that, in practice, the definition of diminished responsibility was "obscure, and difficult to apply in individual cases". ${ }^{11}$ Thereafter, the Scottish Law Commission received instruction from Scottish Ministers that there existed a remit for them to consider:

1. The tests to establish insanity (either as a defence or as a plea in bar of trial) and the plea of diminished responsibility

2. Issues of the law of evidence and procedure involved in raising and establishing insanity and diminished responsibility

3. Recommendations for reform; and

4. Consequent upon any recommendations for reform, to consider what changes, if any, should be made to the powers of the courts to deal with persons in respect of whom insanity (either as a defence or as a plea in bar of trial) or diminished responsibility has been established. ${ }^{12}$

In the report which followed, the Scottish Law Commission proposed abolishing the common law test for diminished responsibility and introducing a statutory definition. ${ }^{13}$ In support of codification, they referred to the recent decision of Galbraith:

We note that the decision in the Galbraith case did not purport to deal with every issue involved with the plea. In Galbraith the Court itself stated that its views were tentative and might have to be modified or refined in later cases. We accept that the general positive criteria for the plea as laid down in that decision have met with general

\footnotetext{
${ }^{10}$ Millan Committee, Review of the Mental Health (Scotland) Act 1984 (2001), Recommendation 29.6, 358.

${ }^{11}$ Ibid at 357.

${ }^{12}$ Scottish Parliament, Criminal Justice and Licensing Scotland Bill, Policy Memorandum (2009) 77.

${ }^{13}$ Scottish Law Commission, Report on Insanity and Diminished Responsibility (2004) 32.
} 
approval. However the new test also excludes two specific conditions (voluntary intoxication and psychopathic personality disorder) from the scope of the plea, and these exclusions have been controversial. Indeed, the response to our proposals on the exclusions has led us to recommend that the law in relation to them should be clarified or altered. But it would be an undesirable approach to law reform to change part of the Galbraith test by statute while leaving the rest in its common law form. Moreover, as one of our consultees pointed out, the limits to the scope of the plea involve considerations of public policy, which are best addressed by the legislature. ${ }^{14}$

The Scottish Law Commission further noted that other legal systems which had introduced a plea of diminished responsibility had done so by statute and that a "statutory definition does not prevent judicial activism and creativity where that is required for legal development". ${ }^{15}$

\section{(2) The introductory of a statutory definition}

The statutory definition of diminished responsibility was subsequently introduced into Scots law following the Criminal Justice and Licensing (Scotland) Act 2010 (which inserted section 51B into the Criminal Procedure (Scotland) Act 1995):

A person who would otherwise be convicted of murder is instead to be convicted of culpable homicide on the grounds of diminished responsibility if the person's ability to determine or control conduct for which the person would otherwise be convicted of murder was, at the time of the conduct, substantially impaired by reason of abnormality of mind.

The wording of section 51B (1) confirmed that diminished responsibility would have no application in the context of attempted murder- referring to 'murder' only. The position in relation to attempted murder had been less clear under common law. In Blake it was commented:

The state of mind of the accused may be such, short of insanity, as to reduce the quality of his act from attempted murder to assault. A man may suffer from some infirmity or aberration of mind or impairment of the intellect to such an extent as to render him not fully accountable in law for his actions. Such a man is described as being a man of

\footnotetext{
${ }^{14}$ Ibid at 31-32.

${ }^{15}$ Scottish Law Commission (n 13) 32.
} 
diminished responsibility. If he has not been fully responsible for what he has done, he is guilty not of attempted murder but of assault. ${ }^{16}$

Shortly before the enactment of the 2010 Act, the Crown appeal of Kerr considered the issue again, concluding:

We accept the submission on behalf of the respondent that the actus reus of murder and attempted murder differs in the sense that in the completed crime of murder the consequence is the death of the victim whereas that is not achieved in the attempted crime. However, it is clear that the mens rea for the crime of murder and attempted murder is identical. ${ }^{17}$

The court reserved its opinion in relation to the effect of the statutory provisions which were not yet in force ${ }^{18}$, noting that neither the Scottish Law Commission's Report on Insanity and Diminished Responsibility, the statutory provisions contained within the 2010 Act, nor English law (where it is not accepted as a defence to attempted murder) were of any assistance when considering the question. ${ }^{19}$ The Scottish Law Commission's report itself was clear that the plea of diminished responsibility should not be extended beyond murder ${ }^{20}$, but the discussion in Kerr illustrates that there is logic to concluding that evidence of diminished responsibility should give rise to an assault or aggravated assault conviction in the context of an attempted murder charge since the mens rea required for murder and attempted murder is identical. ${ }^{21}$ Nevertheless, this was not the position adopted by the 2010 Act.

\section{POST CODIFICATION CASES}

The 2010 Act came into force in 2012. Since then, four appeal cases have been reported in which diminished responsibility has been the central issue. Three of these cases have been remitted to the appeal court by the Scottish Criminal Case Review Commission, further suggesting that closer examination of diminished responsibility cases post codification is

\footnotetext{
${ }^{16}$ HM Advocate v Blake 1986 SLT 661.

${ }^{17}$ HM Advocate v Kerr 2011 SLT 430 at para 7.

${ }^{18}$ Ibid at para 5.

${ }^{19}$ HM Advocate v Kerr 2011 SLT 430 at para 9.

${ }^{20}$ Scottish Law Commission (n 13) 44.

${ }^{21}$ Cawthorne v HM Advocate 1968 JC 32.
} 
appropriate. ${ }^{22}$ Three additional sentencing appeals have been reported since 2012 in which the appellant had submitted a plea of diminished responsibility. ${ }^{23}$

In addition, 29 unreported cases have been identified in which an accused sought to rely on diminished responsibility. These cases relate to homicides occurring between 2012 and 2019 and were identified as part of a larger ongoing study on Scottish homicide cases being carried out by the author. Sentencing statements were available for nine of these 29 cases.

Diminished responsibility was accepted in 18 of the 29 unreported cases identified $(62.1 \%) .{ }^{24}$ In nine of these 18 cases where diminished responsibility was accepted, medical disposals were sanctioned by the court (52.6\%). In seven of these nine cases, the disposal was detention at the state hospital, suggesting that the mental abnormality in question was severe.

Amongst the unreported cases in which diminished responsibility was accepted but medical disposals were not ordered, the length of prison sentences ranged from three years and seven months to 16 years. Two offenders received deferred sentences.

By way of context, between 2012/13 and 2018/19, the total number of people who had proceedings brought against them for homicide was $790 .^{25}$ This would suggest that a relatively small percentage of those accused of homicide in Scotland seek to rely on diminished responsibility. Despite this, and the fact that an analysis of unreported cases suggests a high success rate with the plea, it remains important to examine the landscape of diminished responsibility post codification.

\section{BURDEN AND STANDARD OF PROOF}

\footnotetext{
${ }^{22}$ Graham v HM Advocate, 2018 SCCR 347; Lilburn v HM Advocate 2015 SCCR 320; Reid $v$ HM Advocate 2013 SCCR 70. Although it must be noted that in all three of these appeals, the conviction was delivered before the change in law relating to diminished responsibility. ${ }^{23}$ In two of these appeals against sentence diminished responsibility had been accepted and the appellant had been sentenced on that basis. In the third appeal against sentence, diminished responsibility had been pled unsuccessfully and the appeal concerned the punishment part related to the mandatory life sentence for the murder conviction. ${ }^{24}$ In one of the cases where diminished responsibility was rejected, it was nevertheless accepted that the accused did not intend to kill. On this basis a guilty plea was accepted to culpable homicide. See Sentencing statement for HM Advocate v Mark Foster.

${ }^{25}$ Scottish Government, Criminal Proceedings in Scotland, 2018-19 (2020), as calculated from table 4a.
} 


\section{(1) Discharging the reverse burden}

Section 51B (4) states that "It is for the person charged with murder to establish, on the balance of probabilities, that the condition set out in subsection (1) is satisfied". This reverse burden exists due to the plea being based on a claim about the internal mental condition of the accused - a fact which would be objectively difficult for the Crown to prove, particularly given that they cannot compel an accused to give evidence or be examined on the issue of their mental health. ${ }^{26}$

Although section 51B does not place a statutory requirement on the defence to provide expert evidence in support of their claim, given the operation of the reverse burden, reference to expert testimony is likely. Certainly, in England and Wales it has been established that medical evidence is a practical necessity because of the reverse burden which exists. ${ }^{27}$ The Scottish appeal court has reserved its opinion on this point. ${ }^{28}$

The admission of expert evidence in Scottish criminal trials is now governed by the Supreme Court decision in Kenned $y^{29}$. The four-part test holds that skilled witnesses can give evidence of their opinions to assist the court as long as:

1. Expert evidence is necessary to assist the court

2. The expert has the necessary knowledge and experience

3. The expert's presentation and assessment of evidence is impartial

4. Their discipline is underpinned by a reliable and established body of knowledge Historically, the admission of expert evidence was a feature of diminished responsibility which led to judicial scepticism of the plea itself: it was feared that it would potentially require the admission of expert evidence as a matter of common practice and that such experts would usurp the function of the court. ${ }^{30}$ Certainly, previous appeals have been based on experts commenting on whether the accused was acting with diminished responsibility ${ }^{31}$ (that is to say, commenting on the ultimate issue before the court). Kennedy has made clear

\footnotetext{
${ }^{26}$ Lilburn v HM Advocate 2011 SLT 861.

${ }^{27} R v$ Bunch [2013] EWCA Crim 2498.

${ }^{28}$ Graham v HM Advocate 2018 SCCR 347.

${ }^{29}$ Kennedy v Cordia Services LLP [2016] UKSC 6

${ }^{30}$ Carraher v HM Advocate 1946 JC 108.

${ }^{31}$ See Martindale v HM Advocate 1994 SLT1093 where it is commented that "(1) there was evidence from the defence psychiatrist Dr Ritson that the appellant was suffering from diminished responsibility at the time of the incident, that he was not in his right mind and that he was in a state of mind bordering on mental disease".
} 
that an expert may address the ultimate issue before the court ${ }^{32}$, but it remains the case that the expert must not do this by reference to the standard of proof ${ }^{33}$. Whilst judicial attitudes towards expert evidence have evolved, with expert testimony now being admitted across a wide range of cases (not just those which involve a plea of diminished responsibility ${ }^{34}$ ), there continues to exist reservation about the admission of expert opinion on new and developing sciences. $^{35}$

Post codification, the role of the expert in diminished responsibility cases has been considered by the appeal court. ${ }^{36}$ In Graham, the court considered whether a psychologist meets the necessary qualification required of an expert witness when being asked to consider how drugs and alcohol may have interacted with mental disorder. The court suggested that in such circumstances, evidence could not be provided by a psychologist on this matter but would have to be provided by someone medically trained, such as a psychiatrist (but invited the Scottish Law Commission to give further consideration to the qualifications which should be demanded by the court in murder trials as part of their ongoing review of homicide.) ${ }^{37}$ For commentators such as Hallett, an increased reliance on psychiatric evidence in diminished responsibility cases would be problematic. For him, psychiatric evidence has already been given too much authority, leading to an obfuscation of how moral responsibility is assigned in diminished responsibility cases. ${ }^{38}$

In terms of assessing whether a reverse burden has been discharged, warning has previously been given in civil cases against using arithmetical approaches of assessment:

\footnotetext{
${ }^{32}$ Kennedy v Cordia Services LLP [2016] UKSC 6 at para 50. Chalmers and Leverick also exemplify the fact that an expert can effectively address the ultimate issue before the court by adopting the language of the courts without using the language of 'diminished responsibility'. In the unreported case of HM Advocate $v$ Gorrie (Alison), the psychiatrist giving evidence had adopted the language used by Lord Roger in Galbraith, J Chalmers and F Leverick (n 2) para 11-16 footnote 27.

${ }^{33}$ Hendry v HM Advocate 1987 JC 63.

${ }^{34}$ For a discussion of the development of psychological evidence into law see F E Raitt and S $\mathrm{M}$ Zeedyk, The implicit relation of psychology and law: Women and syndrome evidence (London: Routledge, 2000) ch 2 esp.

${ }^{35}$ See for example Young $v$ HM Advocate 2014 SCCR 649.

${ }^{36}$ Graham v HM Advocate 2018 SCCR 347 at para 114.

${ }^{37}$ Ibid at para 124. The Scottish Law Commission is considering the qualifications of experts in diminished responsibility cases as part of their current review.

${ }^{38}$ N Hallett, "Psychiatric Evidence in Diminished Responsibility" (2018) 82(6) Journal of Criminal Law 442.
} 
The court arrives at its conclusion by considering whether on an overall assessment of the evidence (i.e. on a preponderance of the evidence) the case for believing that the suggested event happened is more compelling than the case for not reaching that belief (which is not necessarily the same as believing positively that it did not happen) and not by reference to percentage possibilities or probabilities. ${ }^{39}$

This warning was referred to in Rodgers when discussing how the balance of probabilities should be understood.

\section{(2) Defining the standard of proof}

The question of how the standard of balance of probabilities should be understood is one which has been raised before. ${ }^{40}$ Post codification, the Scottish appeal court has been faced with this question explicitly in the context of diminished responsibility ${ }^{41}$. In Rodgers, it was noted that in the original trial, the judge referred to a mathematical account which had earlier been provided by defence counsel:

All that it means in practical terms is that something is more probable than not, I think [defence counsel] put it into percentage terms, something is more likely than not if it's $51 \%$ playing $49 \%$. It could be 70 playing 30 or 90 playing 10 but a minimum, it has to be more likely than not which is $51 \%$ playing $49 \%$, that's as colloquially as I can put the matter. So it's more likely than not, and that is the burden of proof that the defence bear in this trial. ${ }^{42}$

The court concluded that no material misdirection existed in relation to the direction which had been provided. In support of this conclusion, it was recognised that the concept has historically been expressed similarly in both legal practice and Scottish academic commentary. ${ }^{43}$ However, the dangers of adopting this approach were recognised.

In conclusion, post codification, diminished responsibility has remained static in terms of how the concept of the balance of probabilities is conveyed to jurors and has narrowed in respects of the role of expert evidence: where the mental condition in question co-exists with

\footnotetext{
${ }^{39}$ re A (Children) (Care Proceedings: Burden of Proof) [2018] 4 WLR 117 at para 58.

${ }^{40}$ See for example Lord Nicholls's comments in re(H) Minors [1996] AC 563.

${ }^{41}$ Rodgers $v$ HM Advocate 2019 SCCR. 230.

${ }^{42}$ Ibid at para 22.

43 On this point the court referred to F Davidson, Evidence (2007) para 4.84, citing Davies $v$ Taylor [1974] AC 207, Lord Simon at 219-220.
} 
drugs and alcohol, expert evidence offered must be provided by a psychiatrist. This is especially significant given the overlap between intoxication and mental conditions. This was a key issue in three of the seven appeal cases examined (including Graham) and twelve of the 29 unreported cases examined (41.4\%).

\section{E. WHERE MENTAL ABNORMALITY COEXISTS WITH VOLUTARY INTOXICATION}

\section{(1) Clarifying the rule}

Galbraith did not go beyond stating the rule in relation to the role of drugs and alcohol ${ }^{44}$ and did not refer to unreported case law which had. ${ }^{45}$ As such, the clarification on this point was viewed as a significant basis to justify the introduction of a statutory definition. ${ }^{46}$ Section $51 \mathrm{~B}$ (3) states that:

The fact that a person was under the influence of alcohol, drugs or any other substance at the time of the conduct in question does not of itself-(a)constitute abnormality of mind for the purposes of subsection (1), or (b)prevent such abnormality from being established for those purposes.

Therefore, although voluntary drug and/or alcohol intoxication cannot form the basis of the defence itself, the influence of drugs and alcohol will not rule out diminished responsibility per se. Section 51B provided scope for diminished responsibility to develop an appreciation of the complex interplay between mental abnormality and voluntary intoxication - something which had not been achieved under common law:

discussion of the effects of intoxication combined with another abnormality of mind assumes that the two are separable in some way. In many cases, however, the two may be linked, in that the abnormality of mind may be causally linked to the intoxication. $^{47}$

\footnotetext{
${ }^{44}$ Galbraith v HM Advocate (No.2) 2002 JC 1 at para 54.

${ }^{45}$ HM Advocate v McLeod, unreported, as discussed by J Chalmers and F Leverick (n 2) at para 11-13.

${ }^{46}$ Scottish Law Commission (n 13).

${ }^{47} \mathrm{~J}$ Chalmers and F Leverick (n 2) at para 11-14.
} 


\section{(2) A narrow approach post codification}

Post codification, the application of section 51B (3) was considered in detail in Rodgers. ${ }^{48}$ This case involved the unprovoked killing of a young female at a party, witnessed by others. The accused suffered from long standing psychiatric problems, associated with a "challenging childhood" 49 and had attempted suicide on more than one occasion. On the night of the offence, he had been witnessed expressing suicidal ideation. At the time of the offence, the accused was taking prescribed medication (the anticonvulsant and mood stabiliser, 'lamotrigine', and the benzodiazepine, 'Valium') but had refused counselling and psychiatric services and continued to consume large quantities of alcohol, contrary to medical advice. ${ }^{50}$

Evidence was led at trial which suggested that, at the time of the offence, the accused was suffering from a mental disorder as well as being under the influence of alcohol and drugs. Forensic psychiatrist, Dr Isobel Campbell, concluded that the appellant was suffering from Emotionally Unstable Personality Disorder (EUPD), marked by a tendency towards impulsivity and lack of consideration for consequences, as well as Borderline Personality Disorder. ${ }^{51}$ She noted in evidence that the contribution of drugs and alcohol in combination with these disorders would be "unhelpful". ${ }^{2}$ Crown psychiatrist, Dr Racheal Sibbett, similarly concluded that the appellant was suffering from EUPD and noted the likely contribution of intoxication in the alleged offence. ${ }^{53}$

The appeal against conviction specifically considered how the jury should be directed where evidence of both mental abnormality and intoxication exists. It was submitted that the trial judge had erred in directing the jury that it was open to them to find either that the substantial cause of the appellant's actions was the abnormality of mind or that it was his use of alcohol or drugs at that time. In its judgement, the court emphasised that the key issue for consideration is whether, despite the intoxication, the accused was suffering from an abnormality of mind which substantially impaired the ability to control conduct; abnormality need not be the only cause of impairment in order for diminished responsibility to operate, but it must be substantial. In considering the application of section 51B, the court noted the

\footnotetext{
${ }^{48}$ Rodgers $v$ HM Advocate 2019 SCCR 230.

${ }^{49}$ Ibid at para 4.

${ }^{50}$ bid.

${ }^{51}$ bid at para 17 .

52 bid at para 18 .

${ }^{53}$ bid at para 20 .
} 
continued relevance of the common law principles of diminished responsibility, referring to Brennan ${ }^{54}$ and the fact that the impairment in question "must not be brought on by the voluntary ingestion of drink or drugs."

The court concluded that the judicial direction which had been offered on this point at the original trial was erroneous. ${ }^{56}$ However, although this was considered a material error given the centrality of the issue - it could not be concluded that it had given rise to a miscarriage of justice since evidence had been led which pointed to the effect of combining Valium and alcohol ("paradoxical aggression" and a disinhibition of aggression): ${ }^{57}$

Even on the assumption that the appellant's ability was impaired as a consequence of a combined effect of voluntary alcohol/drug ingestion and a mental abnormality, the correct verdict was one of murder. ${ }^{58}$

In the unreported case of Kmieciak, Lord Burns appears to have adopted a similar understanding, whilst also recognising the role that intoxication had on the offender's behaviour. Although the plea was accepted in that case, it was commented:

You appear to be someone who is vulnerable to psychotic disturbance when you have taken illegal substances but having regard to the plea it was accepted on the basis that the abnormality at the time was caused by natural circumstances and not drug intake. $^{59}$

\section{(3) Tensions and contradictions}

Yet, in other unreported cases identified, where guilty pleas to culpable homicide on the basis of diminished responsibility were accepted by the Crown, a different approach appears to have been taken. In Loughton, Lord Beckett offers insight into this decision when relaying comments provided by a forensic psychiatrist:

\footnotetext{
${ }^{54}$ Brennan v HM Advocate, $1977 \mathrm{~J}$ C 38.

${ }^{55}$ Rodgers $v$ HM Advocate 2019 SCCR 230 at para 32.

${ }^{56}$ Ibid at para 33.

${ }^{57}$ Ibid at para 35.

58 Ibid at para 36.

59 The Courier, "Man who stabbed friend to death in Perth after "hearing voices" jailed for seven and a half years", available at https://www.thecourier.co.uk/fp/news/local/perthkinross/914232/man-who-stabbed-friend-to-death-in-perth-after-hearing-voices-jailed-forseven-and-halfyears/\#: :text=Jakub\%20Kmieciak\%20admitted\%20killing\%20Rafal,homicide\%2C\%20due $\% 20$ to\%20diminished\%20responsibility.
} 
He explains that there is a complex interplay of problems associated with your personality disorder and substance use which has been responsible for violence in the past and these factors continue to be the main risk factors for future violence. ${ }^{60}$

A similarly approach is also evident in Little:

[the accused] had been under the influence of Amphetamine, which had exacerbated his personality disorder and was deemed to have caused "diminished responsibility". 61

Further analysis of unreported cases suggests that diminished responsibility is not always applied or accepted in relevant circumstances. For example, in one case it was accepted that the accused's actions had arisen out of unforeseen side effects of prescribed drugs ${ }^{62}-\mathrm{a}$ position better represented by the full (but rarely advanced) defence of automatism. Unforeseen side effects of medication also formed part of the submission made in a second case where diminished responsibility was not accepted. ${ }^{63}$ One explanation for this difference could be that a gendered application of the plea exists in practice: four of the 29 unreported cases involved a female accused and in all four cases diminished responsibility was accepted - even where the relevance of the plea was questionable. In one, a female accused was found guilty of culpable homicide by way of diminished responsibility arising from the "strain" that allegations of sexual abuse against her husband (the deceased) had placed her under. ${ }^{64}$ No further mention is made about any specific mental abnormality being experienced by the accused at the time of the killing. Similarly, in another unreported case involving a female accused, a woman was convicted of culpable homicide on the basis of diminished responsibility following a plea of guilty being accepted by the Crown. Here, reference was

\footnotetext{
${ }^{60}$ Sentencing Statement HM Advocate v Steven Loughton, 2020, available at https://www.judiciary.scot/home/sentences-judgments/sentences-andopinions/2020/04/24/hma-v-steven-loughton

${ }^{61}$ Evening Telegraph, "Dundee Killer Charles Little gets $q 10$ years in jail for bow and arrow and knife death", available at https://www.eveningtelegraph.co.uk/fp/breaking-dundeecrossbow-killer-charles-little-gets-10-years-in-jail-over-death-of-gordon-diduca/ ${ }^{62}$ BBC News, "Marlene Torlay admits killing Marie McCracken", available at https://www.bbc.co.uk/news/uk-scotland-glasgow-west-22267573.

${ }^{63}$ Dunfermline Press, "Killer's mental state affected by sex abuse, defence claims", available at https://www.dunfermlinepress.com/news/18003657.killers-mental-state-affected-sexabuse-defence-claims/

${ }^{64}$ BBC News, "Wife walks free after killing husband", available at https://www.bbc.co.uk/news/uk-scotland-glasgow-west-42621029
} 
made only to her alcohol and substance abuse problems. ${ }^{65}$ This case could be cited as an example of the plea operation in circumstances of addiction only (see section F below) but it is more likely that these cases are further evidence of the law's recognised tendency towards utilising medical models for female offending. ${ }^{66}$ Although these four cases represent a very small sample and it is difficult to draw clear conclusions from them, the broader context in which they are occurring must be recognised. Because women kill less frequently than men, their behaviour is more likely to be viewed as aberrant by society. As a result, two competing narratives have tended to prevail: one where femininity is denied due to the violence exhibited (the 'bad' woman) and one where her criminal responsibility is neutralised (the 'mad' woman). ${ }^{67}$

In Graham $^{68}$, the opposite position was adopted despite the apparent relevance of diminished responsibility - again showing tensions between the approach of the appeal court and the operation of the plea in practice. The circumstances of the homicide included voluntary intoxication as well as a claim to mental abnormality (EUPD and also 'battered person syndrome' arising from the domestic abuse she had suffered at the hands of the partner she killed). ${ }^{69}$ Specialist registrar, Dr Morris, who had examined the appellant on behalf of the Crown was of the view that Graham's intoxication would "outweigh any possible evidence of a mental disorder" and that symptoms which could have been attributed to the mental disorder EUPD could also have been explained by the drug and alcohol problems experienced by the appellant. ${ }^{70}$ The second Crown expert, psychiatrist Dr Lenihan, was similarly of the view that despite the EUPD diagnosis, the most prominent issue being suffered by the appellant was her dependence on drugs and alcohol (which could not form the basis of the plea).

${ }^{65}$ BBC News, "Woman Admits brutal killing of neighbour Colin Skilbeck", available at https://www.bbc.co.uk/news/uk-scotland-edinburgh-east-fife-42227195?intlink_from_url=\& ${ }^{66}$ F E Raitt and S M Zeedyk (n 39).

${ }^{67}$ D Kirkwood, "Female Perpetrated Homicide in Victoria between 1985 and 1995" (2003) 36 The Australian and New Zealand Journal of Criminology 152; C Smart, Feminism and the Power of Law (1989); S Weare, "“The Mad", "The Bad", "The Victim": Gendered Constructions of Women Who Kill within the Criminal Justice System" (2013) 2(3) Laws 33. ${ }^{68}$ Graham v HM Advocate 2018 SCCR 347.

${ }^{69}$ For further discussion on Graham see R McPherson, "Battered Woman Syndrome, Diminished Responsibility and Women Who Kill: Insights from Scottish Case Law" (2019) 85(5) Journal of Criminal Law 381.

${ }^{70}$ Graham v HM Advocate 2018 SCCR 347 at para 25. 


\section{F. DEPENDENCY}

\section{(1) Potentially relevant Scottish cases}

In Graham, the appellant's long-term drug and alcohol addiction were recognised explicitly by the psychiatrists who examined her. Although addiction was not the basis of the diminished responsibility plea, it was closely related to the EUPD on which the plea was argued. Perhaps due to the fact that this was not the explicit basis of the plea, the court did not provide specific direction on the whether the mental abnormality required for diminished responsibility can include addiction. Graham's appeal was refused and an unsympathetic approach taken towards her addiction. For example, it is noted that the "appellant's own accounts of her alcohol and drug consumption varied", ${ }^{71}$ but that the consumption on the day of the homicide potentially included prescribed and illegal diazepam, mirtazapene, methadone, lager, Bacardi, and amphetamine. Rather miraculously, the accused was deemed fit for interview on the same day by the forensic medical examiner - a fact not subject to interrogation, given that it was not one of the points of appeal.

In Rodgers, no explicit reference was made to addiction or dependency although it would appear that addiction was present. It is noted that the accused continually mixed alcohol with benzodiazepines, despite being warned of the dangers associated with this ${ }^{72}$, that he had consumed a "large" amount of alcohol at the time of the offence ${ }^{73}$, and in reference to a meeting which occurred between the accused and a friend, it is commented that:

On his arrival, the appellant had..."a bag of alcoholic drinks"....apart from beer and gin, the appellant drank "shots", and "Mickey Finns" (i.e. presumably alcohol laced with drugs). ${ }^{74}$

In combination, these provide a picture that alcohol was a problem in the accused's life and suggest that this was an individual suffering from alcohol addiction (as well as psychiatric problems), even if he did not explicitly identify as alcohol dependent. But since the matter of

\footnotetext{
${ }^{71}$ Ibid at para 13 .

${ }^{72}$ Rodgers v HM Advocate 2019 SCCR 230 at para 7.

${ }^{73}$ Ibid at para 20.

${ }^{74}$ Ibid at para 10.
} 
addiction was not put before the court, and was not suggested by medical evidence, it would have been difficult for the court to elucidate on this point.

In other cases, addiction has been explicitly brought to the attention of the court. In Young it was recognised that the appellant had a history of alcohol and drug abuse. In her appeal against sentence the trial judge commented that, despite this, "it seems unlikely that either drink or drugs played a big part in what happened". ${ }^{75}$ Reporting elsewhere notes that:

Young was on 14 prescription drugs, inhaled solvents daily, and had smoked heroin the morning before the stabbing. ${ }^{76}$

The trial judge's view of this conviction for murder was that:

The jury must have accepted the unanimous evidence of all the psychiatrists that Ms Young was suffering from an abnormality of mind, as now defined in section 51(B) of the 1995 Act, at the time of the offence. However, they must also have concluded that her conduct was not substantially impaired at the time. ${ }^{77}$

At trial, evidence had been provided by six consultant psychiatrists who agreed that the accused was suffering from a "severe personality disorder" comprising of "a mixed personality disorder with emotionally unstable (borderline) narcistic, histrionic and antisocial traits", another psychiatrist diagnosed schizophrenia. ${ }^{78}$ Upon conviction, a mandatory life sentence for murder with a punishment part of 20 years was imposed. One of the submissions made on behalf of the appellant in the appeal against this sentence was that imprisonment was "a more severe punishment" for her, given her vulnerability. This vulnerability arose from her unique background of gender reassignment, personality disorder and impulsivity problems. ${ }^{79}$ This submission was rejected by the court who noted her stable condition and ongoing engagement with the healthcare team in Corton Vale Prison. ${ }^{80}$

\footnotetext{
${ }^{75}$ Young v HM Advocate 2015 SCL 420 at para 5.

${ }^{76}$ Edinburgh Evening News, 2014. 'Transgender killer 'bit prison officer', available at: https://www.edinburghnews.scotsman.com/news/transgender-killer-bit-prison-officer1524152

$\overline{77}$ Young $v$ HM Advocate 2015 SCL 420 at para 8.

${ }^{78}$ Ibid all at para 6.

${ }^{79}$ Ibid at para 14.

${ }^{80} \mathrm{Ibid}$ at para 17
} 
In addition to offering insight into how diminished responsibility has been interpreted post codification, these three appeal cases indicate the severity and complexity of mental health conditions which non-specialised prison facilities will be faced with at any given time.

In Scotland, the court has not been asked to consider dependency as the only basis of diminished responsibility. In theory, such a plea is not ruled out by the drafting of section $51 \mathrm{~B}$, but it would appear to be very unlikely to succeed in practice given the approach adopted in Rodgers and Graham. However, Court of Appeal of England and Wales has addressed the issue of dependency in several cases.

\section{(2) The Court of Appeal in England and Wales}

In Tand $y^{81}$ it was held that the fact finder would need to be persuaded that no choice existed about alcohol consumption before dependency could be included as a mental abnormality for the purposes of diminished responsibility. This position was criticised on the basis that diminished responsibility would be removed from those who were alcohol dependent. ${ }^{82}$

Later case law suggested that alcohol dependency could be considered a psychiatric condition in and of itself, ${ }^{83}$ but in Stewart, it was emphasised that just because a defendant suffers from alcohol dependent syndrome does not mean that an abnormality of mind has been established. ${ }^{84}$ The Privy Council have assumed that this position would also apply to drug addiction. ${ }^{85}$ In Daniel, the court held that any abnormality of mind arising from transient intoxication was irrelevant but held that an exception may arise where the intake was the involuntary result of "irresistible craving or compulsion". ${ }^{86}$ The position now being that diminished responsibility can include drug and/or alcohol dependency ${ }^{87}$ and relevant factors for consideration are: the seriousness and extent of the alcohol dependence, the ability of the

\footnotetext{
${ }^{81} R v$ Tandy [1981] WLR 350.

${ }^{82}$ J Craigie and A Davies, "Problems of Control: Alcohol Dependence, Anorexia Nervosa and the Flexible Interpretation of Mental Capacity Tests" (2019) Medical Law Review 27(2) 215 at 236.

${ }^{83} R v$ Wood [2008] EWCA Crim 1305 at para 9.

${ }^{84} R v$ Stewart [2009] EWCA 593 at para 31.

${ }^{85}$ Daniel v The Queen [2012] U.K.P.C. 15.

${ }^{86}$ Ibid.

${ }^{87} R$ v Richardson [2016] EWCA Crim 577.
} 
defendant to control their alcohol intake, whether the defendant is capable of abstinence and whether there existed reason for drinking more than usual. ${ }^{88}$

Craigie and Davis are of the view that, despite the fact that the diminished responsibility test introduced to England and Wales in 2009 was one which was meant to limit diminished responsibility in such a way that alcoholism could not form the basis of the plea, subsequent interpretation of the mental incapacity test has resulted in it being a recognised basis on which diminished responsibility can be based. ${ }^{89}$

\section{(3) Medico-legal analysis}

Such an approach recognises the relationship between addiction and violence. Over thirty years ago, psychiatrist and behavioural scientist Swanson evidenced a similar corelation between alcohol abuse, mental disorders and violence:

Regression analyses examining relationships between major mental disorders, alcohol abuse, and violent behavior support an overall conclusion that the joint occurrence of any two conditions significantly increases the probability that the remaining condition will also be present. Interestingly, the absolute risk of any one of these conditions given the others is quite variable. For example, among males under age 45 and of lower SES, the probability that violent alcohol abusers will be mentally ill is about 15 percent; the probability that those with dual diagnoses will be violent is about 30 percent; and the probability that the violent mentally ill will be alcohol abusers is about 78 percent. ${ }^{90}$ Craigie and Davies estimate that alcohol dependence exists at a rate of around twice the prevalence of drug dependency, "making it a serious social problem. It is also a complex problem because of the deeply embedded role for alcohol in UK culture". ${ }^{91}$ Craigie and Davies recognise that perceptions of addiction are shaped by historical contexts and influence how society responses to addiction. ${ }^{92}$ They use their analysis of how mental incapacity tests are used in cases involving anorexia as an important point of comparison: anorexia develops

\footnotetext{
${ }^{88} R v$ Stewart [2009] EWCA 593.

${ }^{89} \mathrm{~J}$ Craigie and A Davies (n 82).

${ }^{90}$ J W Swanson, "Alcohol abuse, mental disorder, and violent behaviour: an epidemiologic inquiry" (1993) 17(2) Alcohol Health and Research World 123.

${ }^{91} \mathrm{~J}$ Craigie and A Davies (n 82) at 219.

${ }^{92} \mathrm{~J}$ Craigie and A Davies (n 82) at 237.
} 
out of traits valued by society (thinness, exercise, tendencies towards perfectionism); it is often not seen to be within the control of the person affected by the illness. This is in contrast to alcohol and drug addiction where it is often considered that the individual has a choice over their behaviour.

Problems of addiction are well recognised in Scotland, especially in relation to those engaged with the criminal justice system. It is likely that a significant number of accused who seek to rely on diminished responsibility in future case will have a history of addiction. Even if addiction is not accepted as a sole basis for the diminished responsibility, recognition can still be made about how addiction interacts with mental abnormality.

\section{G. CONCLUSION}

The justification for placing diminished responsibility on a statutory footing arose from the fact that voluntary intoxication would not remove the accused from availing themselves of diminished responsibility. Yet the approach taken towards cases involving intoxication and mental abnormality does not seem to have developed from common law. There existed an opportunity to recognise the complex interplay between intoxication, mental conditions and offending and this has not been realised. Similarly, the appeal court's position remains static on the issue of instruction to jurors on what is meant by the balance of probabilities, despite the dangers of the current approach being recognised. Elsewhere, narrowing of the plea has been suggested in what type of expert is required when mental abnormality interacts with intoxication - something which is likely to have a significant impact on the submission of psychological expertise in practice.

It has been shown that tension exists between the view adopted by appeal court post codification and the operation of the plea in practice. On one reading the operation of the plea in practice is positive, allowing as it does for a realistic understanding of how mental abnormality and intoxication co-exist in practice, but yet, the analysis presented also shows that there may be a gendered application of the plea. There exists a danger that female accused are being afforded leniency in terms of what conditions will satisfy the plea. Whilst diminished responsibility must be accessible to those who need it most, there must also be recognition of the historical tendency towards medicalising female offenders within the 
criminal justice system and the dangers this imposes for women's access to justice more generally.

As would be expected in a small jurisdiction, the appeal court has not been asked to consider a larger number of cases following the codification of diminished responsibility. It is recognised that judicial interpretation of section 51B may develop further as a wider variety of cases are appealed. However, if Scotland wishes to have mental health laws which adequately reflect the lived experiences of those who offend, the relationship between intoxication and mental abnormality must be engaged with in a meaningful manner within the doctrine of diminished responsibility. Lack of access to the plea not only risks injustice in terms of the resulting conviction, but also the treatment which might be afforded to the offender in question. 